\title{
Botulinum C3 Enzyme Changes the Lactate Dehydrogenase Isozyme Pattern of Primary Culture of Neurons
}

\author{
Yasuko WATANABE, Masami MORIMATSU and Bunei SYUTO* \\ Department of Veterinary Medicine, Faculty of Agriculture, Iwate University, Morioka, Iwate 020-8550, Japan
}

(Received 10 August 1999/Accepted 16 November 1999)

ABSTRACT. Changes in the lactate dehydrogenase (LDH) isozyme pattern of primary culture of neurons treated with botulinum C3 enzyme were examined in order to elucidate the functional changes accompanying the morphological change that follows ADP-ribosylation of Rho protein. Primary neurons were prepared from the cerebrum of ICR mouse embryos on day 15 . Neurons were cultured in MEM with $10 \%$ fetal calf serum at $37^{\circ} \mathrm{C}$. In the neurons treated with C3 enzyme, a typical morphological change was observed after $24 \mathrm{hr}$, and the LDH isozyme pattern was changed after $72 \mathrm{hr}$. The ratio of H-subunit to M-subunit in LDH was decreased by $\mathrm{C} 3$ treatment, suggesting the induction of a state of lower intracellular oxygen consumption in neurons in the primary cultures.-KEY wORDS: botulinum C3, C3 enzyme, LDH isozyme pattern, mouse neuron, primary culture.

J. Vet. Med. Sci. 62(3): 249-254, 2000

Botulinum C3 enzyme was first reported as a new type of botulinum toxin with an ADP-ribosyl transferase activity [1]. The C3 enzyme produced by Clostridium botulinum type $\mathrm{C}$ and D strains modifies GTP-binding proteins with molecular masses of $20-25 \mathrm{kDa}$ (small G proteins) [1, 2, 12], some of which have been identified as substrates [4, 5, 7, 14]. The C3 enzyme transfers the ADP-ribosyl residue to Asn41 of Rho protein [19].

C3 enzyme has another unique function of inducing morphological changes in cells incubated with the enzyme. In neural cell lines such as PC-12 [15], C6 and NG108-15 [8], the shape of the cell body is changed and neurite outgrowth is induced when C3 enzyme is added to the culture medium. Furthermore, it has been reported that the microinjection of Rho protein ADP-ribosylated with C3 enzyme into cultured cells results in morphological change [17].

Since the morphological changes of neural cells caused by $\mathrm{C} 3$ enzyme seem to indicate the differentiation of the cells, the effects of C3 enzyme on the induction of differentiation marker enzymes have been examined. C3 enzyme increases the differentiation marker enzymes choline acetyl transferase, acetylcholine esterase and 2', 3'-cyclicnucleotide 3'-phosphohydrolase in NG108-15 and C6 cell lines [8]. These facts suggest that $\mathrm{C} 3$ enzyme has a differentiation-inducing-like activity toward neurons.

Based on these informations, we expect that C3 enzyme has a potential medical use for treatment of neural disorders in which neural differentiation is necessary for recovery. However, the overall functional changes induced by $\mathrm{C} 3$ enzyme have not been clarified in detail. Further studies are required to determine what kind of functional changes

* Correspondence to: Syuto, B., Department of Veterinary Medicine, Faculty of Agriculture, Iwate University, Morioka, Iwate 020-8550, Japan. are induced along with the morphological changes caused by $\mathrm{C} 3$ enzyme in order to obtain information useful for developing C3 enzyme as an exogenous differentiation factor for neurons.

Few studies have been reported on the relationship between differentiation and lactate dehydrogenase (LDH) isozyme change. In this study, we have attempted to analyze the LDH isozyme changes induced along with the morphological changes in primary cultured neurons, and discussed the potential of $\mathrm{C} 3$ enzyme in comparison with nerve growth factor (NGF) and N6, 2'-O-dibutyryl 3', 5'cyclic monophosphate (DBcAMP).

\section{MATERIALS AND METHODS}

Purification of C3 enzyme: C3 enzyme was purified from the culture supernatant of Clostridium botulinum type $\mathrm{C}$ strain Stockholm as previously described [13] with a slight modification: high performance liquid chromatography (HPLC) with a Superdex-200 column (Amersham Pharmacia Biotech., Uppsala, Sweden) was carried out instead of gel filtration with a column of Sephadex G-100 superfine (Pharmacia) in order to prevent activity loss and to save time during the enzyme purification.

Preparation of cells for primary cultures: Primary neurons were prepared from the cerebrum of mouse (ICR) embryos on day 15. Cells were cultured in Eagle's minimum essential medium (MEM) supplemented with $10 \%$ fetal calf serum (FCS) in $95 \%$ air and $5 \% \mathrm{CO}_{2}$ at $37^{\circ} \mathrm{C}$. To inhibit the multiplication of glial cells, $10 \mu \mathrm{M}$ (final concentration) cytosine $\beta$-D-arabinoside (araC) was added to the culture dish on the fourth day [11].

Stimulation of cells: After $72 \mathrm{hr}$ of treatment with araC, $30 \mu \mathrm{g} / \mathrm{m} l$ of C3 enzyme, $500 \mu \mathrm{g} / \mathrm{m} l$ of DBcAMP or $50 n \mathrm{~g} /$ $\mathrm{m} l$ of NGF was added to the cultures. A buffer solution (Dulbecco's phosphate buffered saline (PBS), pH 7.4) was used for the control culture. 
Extraction of cytoplasmic proteins: Cytoplasmic proteins were extracted from the neurons incubated for 3 days with each stimulating agent. The dishes were washed three times with $5 \mathrm{~m} l$ of Dulbecco's PBS, and then supplemented with $500 \mu l$ of $20 \mathrm{mM}$ Tris- $\mathrm{HCl}$ (pH 7.4) containing $1 \%$ Triton$\mathrm{X} 100$ at $32^{\circ} \mathrm{C}$ for $30 \mathrm{~min}$. The partially solubilized cell suspension was transferred to a $1.5-\mathrm{m} l$ plastic tube and sonicated at $28 \mathrm{kHz}$ and $0^{\circ} \mathrm{C}$ for $1 \mathrm{~min}$. Insoluble materials were removed by centrifugation at $10,000 \times \mathrm{g}$ and $0^{\circ} \mathrm{C}$ for $30 \mathrm{~min}$. The protein concentration of the sample was determined by the method of Lowry et al. [10] using bovine serum albmin (BSA) as the standard.

Analysis of LDH isozymes: The LDH isozyme pattern was analyzed by polyacrylamide gel electrophoresis using $6 \%$ slab gels. Twenty-five to $50 \mu \mathrm{l}$ aliquots of the samples (25 $\mu \mathrm{g}$ of protein) were applied per lane and electrophoresed at a constant current of $15 \mathrm{~mA}$ per gel at room temperature until the marker dye reached $5 \mathrm{~mm}$ from the bottom edge of the gel. The gel was incubated in the solution of an LDH isozyme measurement kit (Helena Lab., Urawa, Japan) at $37^{\circ} \mathrm{C}$ for $30 \mathrm{~min}$, followed by densitometry performed at $575 \mathrm{~nm}$ using a Shimazu CS-9300 densitometer. Student's $t$-test method was applied to evaluate the significance of differences.

Protein analysis: Sodium dodecylsulfate-polyacrylamide gel electrophoresis (SDS-PAGE) on $12.5 \%$ gel was performed by the method of Laemmli [9]. The proteins in the gels were stained with silver stain using a commercial kit, Silveststain, according to the manufacturer's protocol for the kit (Nacalai tesque, Kyoto, Japan), followed by densitometry at $510 \mathrm{~nm}$.

Morphological observation: The neurons cultured for the indicated period were fixed with $4 \%$ paraformaldehyde and stained with hematoxylin, followed by observation with an IX70 microscope (Olympus, Tokyo, Japan).

\section{RESULTS}

Morphological change: Neurons stimulated with C3 enzyme, DBcAMP or NGF for $24 \mathrm{hr}$ under the primary cultures underwent similar but not identical morphological changes in their cell bodies and processes during the stimulation (data at $24 \mathrm{hr}$ are not shown, but typical changes after 3 days are shown in Fig. 1). The cell bodies of neurons treated with $\mathrm{C} 3$ enzyme turned small and round, and the neurons formed many thin processes (Fig. 1A and 1B). On the other hand, in the neurons treated with DBcAMP or NGF, the shape of the cell body remained asteroidal, and a few thick processes were formed (Fig. 1C and 1D).

Effect of C3 enzyme on expression of proteins: Analysis of the protein components of neurons in the primary cultures by SDS-PAGE showed that at least three protein components were changed in concentration in the neurons treated with C3 enzyme (Fig. 2). The concentrations of two components with molecular masses of $70 \mathrm{kDa}$ and $40 \mathrm{kDa}$ were increased by $\mathrm{C} 3$ treatment, while that of a $20-\mathrm{kDa}$ component was decreased.
Changes in the LDH isozyme pattern: The effect of C3 enzyme on the LDH isozyme pattern of neurons in the primary cultures was examined. A change in the pattern of LDH isozymes was observed after 3 days of treatment with C3 enzyme (Fig. 3A and 3B). There was a time lag of $48 \mathrm{hr}$ between the morphological change and the change of the $\mathrm{LDH}$ isozyme pattern. The total activities of $\mathrm{LDH}$ of neurons in the primary cultures were essentially unchanged by $\mathrm{C} 3$ treatment (data not shown), but the LDH isozyme pattern was changed (Fig. 4). In the neurons treated with C3 enzyme, LDH1 and LDH2 decreased, while LDH4 and LDH5 increased, and LDH3 remained at the control level. On the other hand, in the neurons treated with DBcAMP or NGF, LDH1 and LDH2 increased, while LDH4 and LDH5 decreased.

\section{DISCUSSION}

It has been reported that $\mathrm{C} 3$ enzyme induced shape changes and process formation in PC-12 cells [15], and that C3 enzyme and DBcAMP induced similar shape changes and process formation in NG108-15 cells [8]. In the present study, the morphological changes caused by C3 enzyme were slightly different from those caused by NGF or DBcAMP. This difference may be due to the difference of cells used (cell lines versus primary cultured cells) and due to differences of signal transduction mechanisms, since DBcAMP activates protein kinase A [18], NGF activates a MAP-kinase [3, 6, 16] and C3 enzyme modifies Rho protein [19].

In previous studies, it was not clarified whether or not the morphological changes were accompanied by changes of the cell components. The present SDS-PAGE experiments revealed that the amounts of proteins with molecular masses of $70 \mathrm{kDa}$ and $40 \mathrm{kDa}$ were increased, while the amounts of a $20 \mathrm{kDa}$ protein was decreased by $\mathrm{C} 3$ enzyme treatment, suggesting enhancement and suppression of the synthesis of these proteins, respectively. Although these molecular changes may be related to the morphological changes of the neurons, their functions are not known.

We next analyzed the LDH isozyme pattern of the cells. The results showed that the changes in the LDH isozyme pattern occurred later than the morphological changes after treatment with $\mathrm{C} 3$ enzyme. The change in the $\mathrm{LDH}$ isozyme pattern was detected on day 3 , while the morphological change was observed within $24 \mathrm{hr}$ after C 3 treatment. This time lag suggests that the expression of the LDH subunit gene is induced after the morphological change.

Qualitative changes in the LDH isozyme pattern were found with time, characterized by a shift toward an enhanced synthesis of the $\mathrm{H}$ subunit [20]. In our experiments, the overall $\mathrm{H} / \mathrm{M}$ ratio was decreased from 0.95 to 0.67 in the neurons treated with $\mathrm{C} 3$ enzyme. This indicates that the production of the M-subunit of LDH was enhanced and the H-subunit production was suppressed. The synthesis of $\mathrm{LDH}$ isoenzymes containing mainly $\mathrm{M}$ subunits is specifically induced by hypoxia in rat astrocytes in primary 


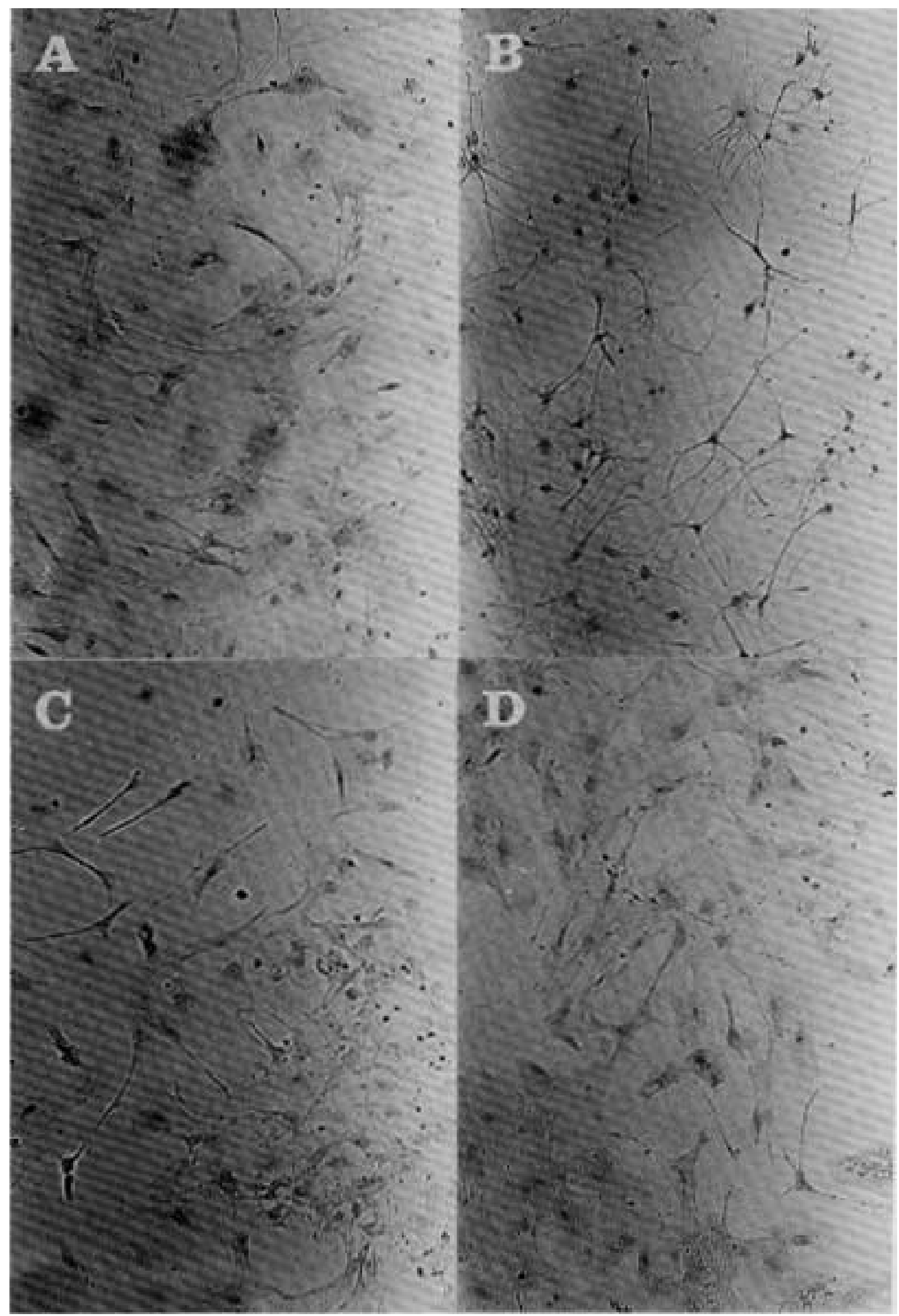

Fig. 1. A morphological change of neurons in the primary cultures treated with stimulants. Photographs on day 3 after treatment. (A) PBS as a control, (B) C3 enzyme, $30 \mu \mathrm{g} / \mathrm{m} l$, (C) DBcAMP, $500 \mu \mathrm{g} / \mathrm{ml}$, (D) NGF, $50 n \mathrm{~g} / \mathrm{m} l$. The cultures were stained with hematoxylin. Magnification: $\times 10$. 


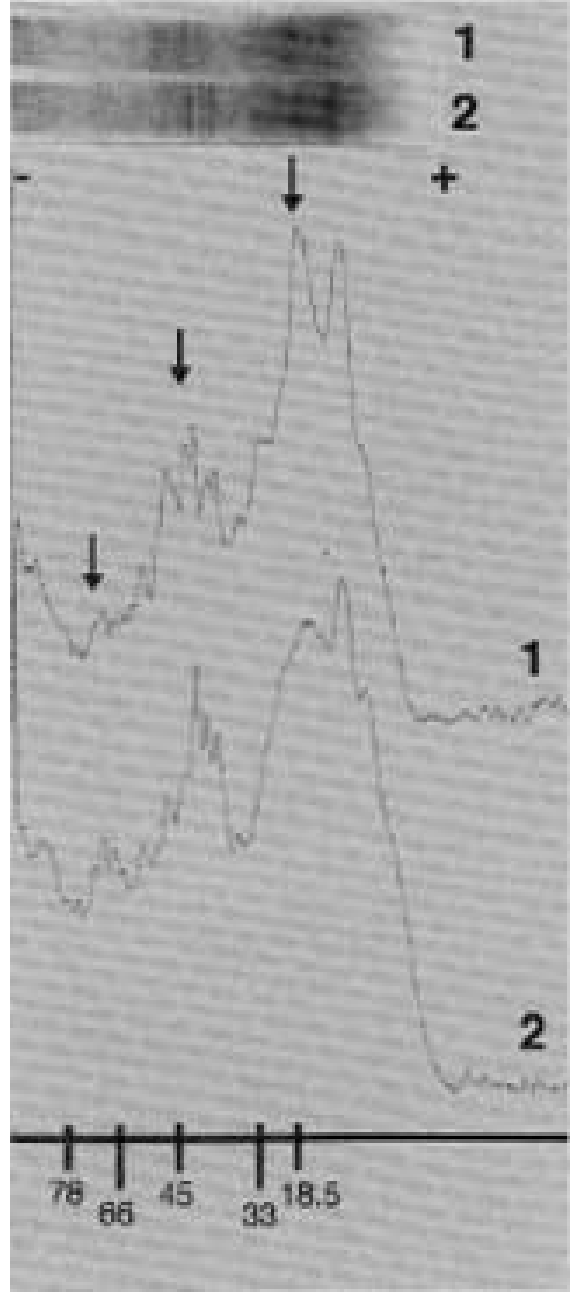

Fig. 2. Changes of protein components of neurons in the primary cultures treated with C3 enzyme as shown by SDS-PAGE analysis. The cytoplasmic proteins extracted from primary cultured neurons were treated with $0.01 \% \mathrm{BPB}$ and $5 \%$ glycerol at $100^{\circ} \mathrm{C}$ for $2 \mathrm{~min}$ in the presence of $1 \%$ SDS and 5\% 2 -mercaptoethanol, and a $25-\mu \mathrm{g}$ aliquot of the protein sample was loaded onto a $12.5 \%$ polyacrylamide slab gel containing $1 \%$ SDS. Lane 1: PBS as a control; lane 2: C3 enzyme $30 \mu \mathrm{g} / \mathrm{ml}$. Molecular mass markers of 78, 66, 45,33 , and $18.5 \mathrm{kDa}$ were coelectrophoresed. The three indicated protein components were changed in concentration in the neurons treated with $\mathrm{C} 3$ enzyme (arrows).

cell cultures [21]. In our experiments, although the Msubunit production in neurons treated with C3 enzyme was increased, the medium was not hypoxic in the primary cultures. This suggests that the metabolic conditions inside the neurons may have been in a state of lower oxygen consumption, resulting in induction of M-subunit production

The treatment of neurons with DBcAMP and NGF caused changes in the LDH isozyme pattern opposite to those caused by $\mathrm{C} 3$ enzyme treatment. The increased H/M ratio found here was similar to that previously reported in a study showing that the synthesis of the H-subunit was developmentally enhanced with time [20]. The enhanced production of the $\mathrm{H}$-subunit induced by DBcAMP in our experiments is considered to be a normal response of neurons. These observations suggest that the expression of the LDH subunits in neurons is controlled by two routes; one route for the exogenous factor, $\mathrm{C} 3$ enzyme, and another route for the endogenous factor, DBcAMP. The route influenced by the $\mathrm{C} 3$ enzyme may affect the induction of neurite formation under conditions such as anaerobic state that occurs during ischemia.

\section{REFERENCES}

1. Aktories, K. and Frevert, J. 1987. ADP-ribosylation of a 21$24 \mathrm{kDa}$ eukaryotic protein(s) by C3, a novel botulinum ADP-ribosyltransferase, is regulated by guanine nucleotide. Biochem. J. 247: 363-368.

2. Aktories, K., Weller, U. and Chhatwal, G. S. 1987. Clostridium botulinum type $\mathrm{C}$ produces a novel ADP-ribosyltransferase distinct from botulinum C2 toxin. FEBS Lett. 212: 109-113.

3. Boulton, T. G., Nye, S. H., Robbins, D. J., Ip, N. Y., Radziejewska, E., Morgenbesser, S. D., DePinho, R. A., Panayotatos, N., Cobb, M. H. and Yancopoulos, G. D. 1991. ERKs: a family of protein-serine/threonine kinases that are activated and tyrosine phosphorylated in response to insulin and NGF. Cell 65: 663-675.

4. Braun, U., Habermann, B., Just, I., Aktories, K. and Vandekerckhove, J. 1989. Purification of the $22 \mathrm{kDa}$ protein substrate of botulinum ADP-ribosyltransferase $\mathrm{C} 3$ from porcine brain cytosol and its characterization as a GTP-binding protein highly homologous to the rho gene product. FEBS Lett. 243: 70-76.

5. Didsbury, J., Weber, R. F., Bokoch, G. M., Evans, T. and Snyderman, R. 1989. rac, a novel ras-related family of proteins that are botulinum toxin substrates. J. Biol. Chem. 264: 16378-16382.

6. Gotoh, Y., Nishida, E., Yamashita, T., Hoshi, M., Kawakami, M. and Sakai, H. 1990. Microtubule-associated-protein (MAP) kinase activated by nerve growth factor and epidermal growth factor in PC12 cells. Identity with the mitogen-activated MAP kinase of fibroblastic cells. Eur. J. Biochem. 193: 661-669.

7. Kikuchi, A., Yamamoto, K., Fujita, T. and Takai, Y. 1988. ADP-ribosylation of the bovine brain rho protein by botulinum toxin type C1. J. Biol. Chem. 263: 16303-16308.

8. Komagome, R. 1994. Effects of Botulinum ADPrybosyltransferase (Exoenzyme C3) on neural cells. Jpn. J. Vet. Res. 42: 44

9. Laemmli, U. K. 1970. Cleavage of structural proteins during the assembly of the head of bacteriophage T4. Nature (Lond.) 227: 680-685.

10. Lowry, O. H., Rosebrough, N. J., Farr, A. L. and Randall, R. J. 1951. Protein measurement with the Folin phenol reagent. J. Biol. Chem. 193: 265-275.

11. Matsuoka, I., Syuto, B., Kurihara, K. and Kubo, S. 1987. ADP-ribosylation of specific membrane protein in pheochro- 

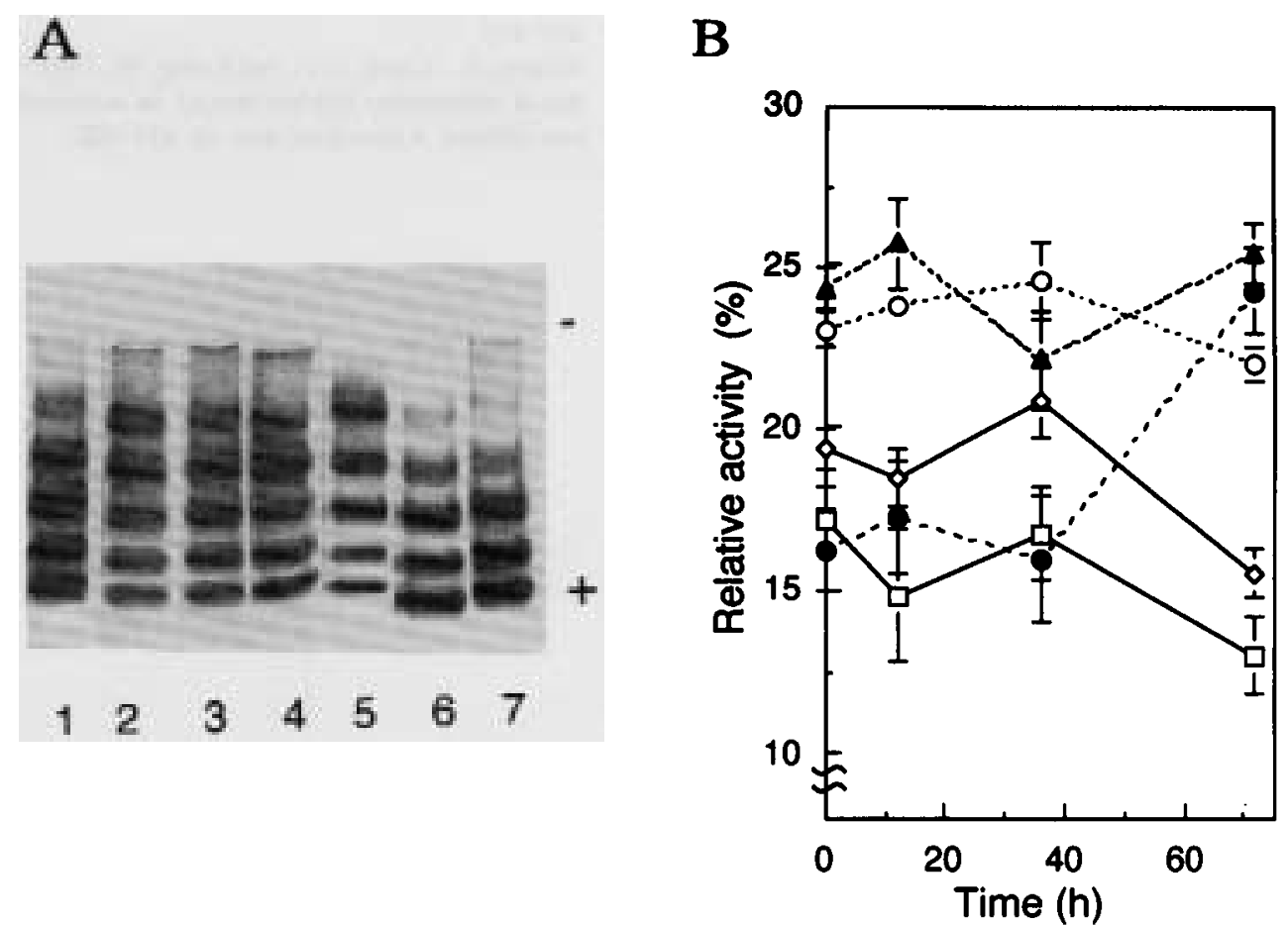

Fig. 3. Changes of the LDH isozyme pattern in neurons treated with C3 enzyme. (A) PAGE analysis of LDH isozymes. An aliquot of the cytoplasmic extract containing $25 \mu \mathrm{g}$ of protein was loaded on a $6 \%$ polyacrylamide slab gel. Lane 1: PBS as a control (72 hr); lanes 2-5: 6, 12, 36, $72 \mathrm{hr}$, respectively, treatment with C3 enzyme, 30 $\mu \mathrm{g} / \mathrm{m} l$; lane 6: DBcAMP, $500 \mu \mathrm{g} / \mathrm{m} l(72 \mathrm{hr})$; lane 7: NGF, $50 \mathrm{ng} / \mathrm{ml}(72 \mathrm{hr})$. (B) Time dependence of the changes of the LDH isozyme pattern of neurons treated with C3 enzyme. LDH1 $(\square)$, LDH2 $(\diamond)$, LDH3 $(\bigcirc)$, LDH4 $(\boldsymbol{\Delta})$, LDH5 (

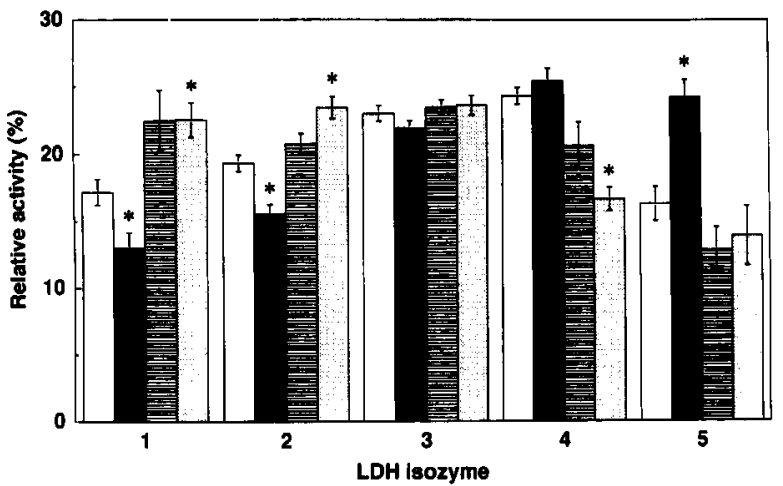

Fig. 4. Changes of the LDH isozyme pattern of neurons treated with $\mathrm{C} 3$ enzyme. Each column shows the percentage of a particular LDH isozyme activity relatived to the total. White column: PBS as a control $(\mathrm{n}=19)$; black column: $\mathrm{C} 3$ enzyme, $30 \mu \mathrm{g} / \mathrm{m} l(\mathrm{n}=16)$; striped column: DBcAMP $500 \mu \mathrm{g} / \mathrm{m} l(\mathrm{n}=9)$; dotted column: NGF $50 \mathrm{ng} / \mathrm{ml}(\mathrm{n}=8)$. Vertical bars represent \pm standard errors. *: $P<0.01$; significantly different from PBS control by Student's $t$-test.

mocytoma and primary-cultured brain cells by botulinum neurotoxins type C and D. FEBS Lett. 216: 295-299.

12. Morii, N., Sekine, A., Ohashi, Y., Nakano, K., Imura, H., Fujiwara, M. and Narumiya, S. 1988. Purification and prop- erties of the cytosolic substrate for botulinum ADPribosyltransferase. J. Biol. Chem. 263: 12420-12426.

13. Moriishi, K., Syuto, B., Yokosawa, N., Oguma, K. and Saito, M. 1991. Purification and characterization of ADPribosyltransferases (exoenzyme C3) of Clostridium botulinum type C and D strains. J. Bacteriol. 173: 6025-6029.

14. Narumiya, S., Sekine, A. and Fujiwara, M. 1988. Substrate for botulinum ADP-transferase, Gb, has an amino acid sequence homologous to a putative rho gene product. J. Biol. Chem. 263: 17255-17257.

15. Nishiki, T., Narumiya, S., Morii, N., Yamamoto, M., Fujisawa, M., Kamata, Y., Sakaguchi, G. and Kozaki, S. 1990. ADPribosylation of the rho/rac proteins induces growth inhibition, neurite outgrowth and acethylcholine esterase in cultured PC12 cells. Biochem. Biophys. Res. Commun. 167: 265-272.

16. Miyasaka, T., Chao, M. V., Sherline, P. and Saltiel, A. R. 1990. Nerve growth factor stimulates a protein kinase in PC12 cells that phosphorylates microtubule-associated protein- 2 . J. Biol. Chem. 265: 4730-4735.

17. Paterson, H. F., Self, A. J., Garrett, M. D., Just, I., Aktories, K. and Hall, A. 1990. Microinjection of recombinant $\mathrm{p} 21$ rho induces rapid change in cell morphology. J. Cell Biol. 111: 1001-1007.

18. Pelligrino, D. A. and Wang, Q. 1998. Cyclic nucleotide crosstalk and the regulation of cerebral vasodilation. Prog. Neurobiol. 56: 1-18.

19. Sekine, A., Fujiwara, M. and Narumiya, S. 1989. Asparagine residue in the rho gene product is the modification site for 
botulinum ADP-ribosyltransferase. J. Biol. Chem. 264: 86028605.

20. Tholey, G., Roth-Schechter, B. F. and Mandel, P. 1980. Development of glial cells in primary cultures: energy metabolism and lactate dehydrogenase isoenzymes. Neurochem. Res. 5:
847-854.

21. Tholey, G., Copin, J. C. and Ledig, M. 1991. Hypoxia induced metabolism dysfunction of rat astrocytes in primary cell cultures. Neurochem. Res. 16: 423-428. 